\title{
METHODS
}

UDC 616.155.1

doi: https://doi.org/10.15407/ubj89.02.116

\section{A NOVEL METHOD FOR NEGATING COLD AGGLUTINATION INTERFERENCE BY DITHIOTHREITOL DURING COMPLETE BLOOD COUNT AND PERIPHERAL BLOOD SMEAR: A CASE STUDY}

\author{
HAMIT YASAR ELLIDAG*, SIBEL KULAKSIZOGLU, ESIN EREN, NECAT YILMAZ \\ Central Laboratories of Antalya Training and Research Hospital, Antalya, Turkey; \\ e-mail: hayael1980@hotmail.com
}

Cold agglutinin disease is an autoimmune disorder that is characterized by antibodies attacking polysaccharide antigens on one's own erythrocytes. In cold agglutinin disease, hemolysis occurs due to degeneration of erythrocyte membranes and autoagglutination of erythrocytes. Both autoagglutination and hemolysis alter many laboratory test results of the patients, especially complete blood count (CBC) and peripheral blood smear analyses. In our laboratory, we have encountered a blood sample of a 65-years-old man, who was independently diagnosed with cold agglutinin disease, and failed to produce meaningful CBC or peripheral blood smear analysis. Fresh blood samples were taken from the patient, and CBC and peripheral blood smear analyses were repeated with and without water bath incubation at $37^{\circ} \mathrm{C}$. Also, varying amounts of dithiothreitol (DTT) were added to fresh samples without heat treatment prior to blood analysis. Heat treatment at $37^{\circ} \mathrm{C}$ for varying lengths of time failed to improve $C B C$ and peripheral blood smear analysis. On the other hand, addition of DTT into a blood sample of $2 \mathrm{ml}$ in a K3-EDTA tube was sufficient to negate cold agglutination interference during both $C B C$ and peripheral blood smear analyses. The presented method supports the potential for DTT to be used in negating cold agglutination interference during CBC and peripheral blood smear analyses of patients with cold agglutinin disease. The method we describe is very easy and quick with remarkable results.

Key word s: cold agglutinin disease, dithiothreitol, autoimmune hemolytic anemia.

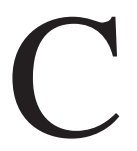

old agglutinin disease is an autoimmune disorder characterized by usually IgM type, and rarely IgA or IgG types, of antibodies directed against polysaccharide antigens on erythrocytes [1]. These antigens are mostly part of the Ii blood system, which are linked to membrane glycosphingolipids, or on the Pr glycophorin in rare cases [1]. Even though mycoplasma infection, lymphoma or an autoimmune disease is the usual suspect, its etiology is idiopathic in general. Clinically, in addition to typical anemia symptoms, clotting of peripheral vessels, such as acrocyanosis in response to cold, livedo reticularis and skin ulcers, and difficulty of and pain during swallowing cold liquids and foods could be observed. Jaundice and splenomegaly could be a part of the clinical manifestation. While the prevalence of cold agglutinin disease is speculated to be about 10 cases per million in Europe, reliable epidemiologic statistics are missing. A study conducted across Norway has found an incidence rate of 1.0 case per million per year [2]. As such, accurate identification of such a rare disorder is crucial for prognosis [3, 4].

In cold agglutinin disease, hemolysis occurs due to degeneration of erythrocyte membranes by antibodies activated in cold, as well as autoagglutination of erythrocytes [1, 4]. Both autoagglutination and hemolysis alter many laboratory test results of such patients. During complete blood count (CBC) analysis of these patients in particular, all parameters

(C) 2017 Hamit Yasar Ellidag et al. This is an open-access article distributed under the terms of the Creative Commons Attribution License, which permits unrestricted use, distribution, and reproduction in any medium, provided the original author and source are credited. 
are affected except for a few [5-7]. Peripheral blood smear is also of limited use due to autoagglutination. Heating in a water bath is utilized to overcome this interference, but this is neither generally effective nor very practical. Here, we present a remarkably practical method for negating such interference in this study.

\section{Materials and Methods}

On a routine day at the laboratory, a technician informed the laboratory specialist that a particular CBC analysis produced abnormal and clinically unexpected results, even though analysis was performed twice in two different instruments of the same model and that the blood sample itself appeared clearer than normal with dark speckles. Consequently, the laboratory specialist contacted the patient and invited him back to the laboratory so that a second blood sample could be taken.

The patient was a 65-year-old male military veteran. The medical history of the patient revealed that initially cyanosis on toes and hands appeared after he had swum in a cold pond. He was then diagnosed with cold agglutinin disease by a hematologist at a different health facility by the cold agglutinin titer method. The patient suffered a severe infection of the respiratory tract afterwards and visited our hospital with complaints of said infection, where blood tests were ordered.

The blood samples were collected from the patient into 2-mL K3-EDTA tubes (BD Vacutainer ${ }^{\circledR}$, Becton, Dickinson and Company, Franklin Lakes, NJ, USA) with a vacutainer system that utilizes vacuum for collecting blood, eliminating the use of syringes. The tube that was used for heat treatment was warmed in the water bath to $37^{\circ} \mathrm{C}$ prior to sample collection and the sample was not allowed to cool before analysis. The dithiothreitol (DTT) (SigmaAldrich, Missouri, USA) solution (0.01 M) was prepared according to the manufacturer's instructions and was kept at $4{ }^{\circ} \mathrm{C}$ away from direct light. DTT was not dispensed directly into the sample tube in fear of cross-reaction with EDTA, and was added immediately after blood collection. Afterwards, the tube was gently mixed on a tube rotator for a few minutes until speckles (agglutination) in the blood sample disappeared. CBC analysis was performed on two Beckman Coulter LH780 Hematology Analyzers (Beckman Coulter, CA, USA).

Written informed consent was obtained from the patient prior to sample collection.

\section{Results and Discussion}

The patient was called and invited back to the hospital, and two fresh blood samples were collected for further analysis. One of the tubes was incubated in a water bath at $37^{\circ} \mathrm{C}$. The other tube was used for CBC and peripheral blood smear (Table; Figure $A$ ). Unfortunately, 30, 60 and 120 minutes of water bath

Complete blood count ( $C B C)$ of the patient. CBC results without dithiothreitol (DTT) are given on the left, while CBC results with added DTT are given on the right. Neither of the samples was heat-treated

\begin{tabular}{|c|c|c|}
\hline $\begin{array}{c}\text { Blood } \\
\text { parameters* }\end{array}$ & Without DTT & With DTT \\
\hline WBC, $10^{9} / \mathrm{l}$ & 12.9 & 7.0 \\
\hline NE, \% & 51.3 & 52.9 \\
\hline LY, \% & 40.8 & 36.5 \\
\hline MO, \% & 4.9 & 8.2 \\
\hline $\mathrm{EO}, \%$ & 1.9 & 2.1 \\
\hline BA, \% & 1.1 & 0.3 \\
\hline NE\#, $10^{9} / \mathrm{l}$ & 6.6 & 3.7 \\
\hline LY\#, 109/l & 5.3 & 2.5 \\
\hline MO\#, 10\%/l & 0.6 & 0.6 \\
\hline EO\#, $10^{9} / 1$ & 0.2 & 0.1 \\
\hline BA\#, $10^{9} / 1$ & 0.1 & 0.0 \\
\hline $\mathrm{RBC}, 10^{9} / \mathrm{l}$ & 0.17 & 3.67 \\
\hline HGB, g/l & 122 & 123 \\
\hline HCT, \% & 2.1 & 35.3 \\
\hline MCV, fL & 126.4 & 96.3 \\
\hline MCH, pg & $\mathrm{NR}^{\dagger}$ & 33.2 \\
\hline MCHC, g/l & NR & 345 \\
\hline RDW, \% & 20.1 & 19.7 \\
\hline PLT, 109/l & 280 & 269 \\
\hline MPV, fL & 6.6 & 6.9 \\
\hline РСТ,\% & 0.183 & 0.186 \\
\hline PDW, fL & 18.3 & 17.6 \\
\hline \multicolumn{3}{|c|}{$\begin{array}{l}\text { *WBC, white blood cell; NE, neutrophil; LY, lympho-- } \\
\text { cyte; MO, monocyte; EO, eosinophil; BA, basophil; } \\
\text { RBC, red blood cell; HGB, hemoglobin; HCT, hemato- } \\
\text { crit; MCV, mean corpuscular volume; MCH, mean cor-- } \\
\text { puscular hemoglobin; MCHC, mean corpuscular hemo- } \\
\text { globin concentration; RDW, red cell distribution width; } \\
\text { PLT, platelet; MPV, mean platelet volume; PCT, platelet } \\
\text { crit; PDW, platelet distribution width. }{ }^{\dagger} \text { NR denotes no re- } \\
\text { sults were obtained. "Cell counts }\end{array}$} \\
\hline
\end{tabular}


$\boldsymbol{A}$

$B$

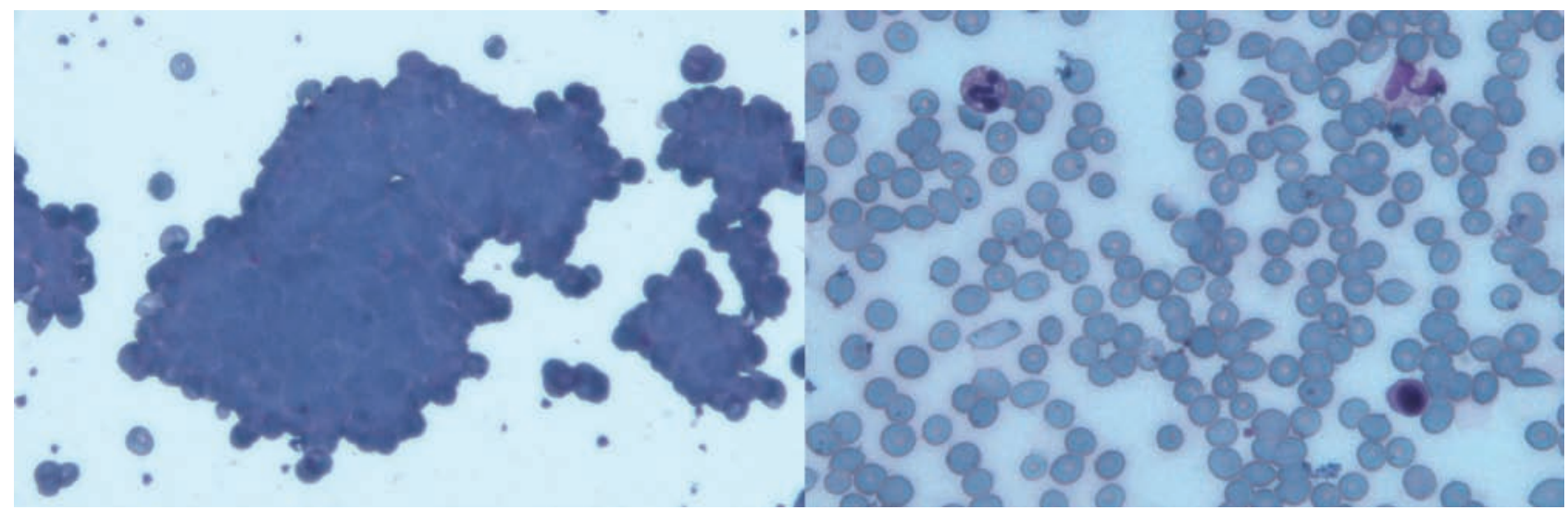

Fig. Peripheral blood smears of the patient. A -Smear without dithiothreitol (DTT); B - Smear with added DTT. Magnification, $400 X$

incubation failed to improve the patient's CBC and smear results (not shown).

The laboratory specialists searched the literature on cold agglutinin disease subsequently. We then realized that we could utilize DTT in this case, which is used in our laboratory to eliminate immune complexes that occasionally arise during immunofixation electrophoresis. Furthermore, Arndt, et al have reported their use of $0.01 \mathrm{M}$ DDT solutions in serologic tests of cold agglutinin disease patients [8]. A solution of 0.01 M DDT was prepared in our laboratory. The patient gave four fresh 2-ml blood samples that were collected in K3-EDTA tubes. 5, 10, 25 or $50 \mu \mathrm{l}$ of $0.01 \mathrm{M}$ DDT solution was added to each tube. These samples were then used for peripheral blood smear and CBC analysis. The hemoglobin concentration of the patient was used as reference during $\mathrm{CBC}$ analysis, in order to compensate for the dilution effect. This is because hemoglobin is measured by optical density and thus not affected by cold agglutination interference $[5,6]$. As a result, we found that the optimal additional DTT amounts were 5 and $10 \mu \mathrm{l}$ of the solution. Nonetheless, when the peripheral blood smears were observed, local agglutination of erythrocytes and bridging between numerous erythrocytes were recorded in the sample supplemented with $5 \mu$ of DTT solution. In conclusion, an addition of $10 \mu \mathrm{l}$ of $0.01 \mathrm{M}$ DTT solution into a blood sample of $2 \mathrm{ml}$ in a K3-EDTA tube is sufficient to negate cold agglutination interference during both CBC and peripheral blood smear analysis of patients with cold agglutinin disease (Table; Figure $B$ ).

CBC is a frequently used test for assessment of general health status. Leukocyte, erythrocyte and platelet counts, and corresponding indexes are determined by CBC analysis, which provide clinicians crucial information for the diagnosis and follow-up of anemias, acute or chronic diseases, hemorrhage propensity, blood cell anomalies and malignancies. Due to antibodies formed against erythrocyte antigens in cold agglutinin disease patients, CBC cannot be performed accurately, and many parameters of these patients, including white blood cell count, red blood cell count, mean corpuscular volume and mean corpuscular hemoglobin concentration in particular, cannot be determined [5-7]. Unfortunately, peripheral blood smears of these patients also fail to produce valid results. Incubation in water bath at $37^{\circ} \mathrm{C}$ is commonly used for negating cold agglutination interference in such patients, but this process, as in this case, is often ineffective, not to mention time-consuming and tiresome.

DTT (also known as Cleland's reagent) is a small redox molecule with the chemical formula $\mathrm{C}_{4} \mathrm{H}_{10} \mathrm{O}_{2} \mathrm{~S}_{2}$. It is generally used for reducing intramolecular and intermolecular disulfide bonds found in proteins. DTT impairs immunoglobulin function by disrupting their disulfide bonds. Because of these properties, DTT can be utilized for negating cold agglutination interference seen in cold agglutinin disease patients $[9,10]$. Another substance that depolymerizes immunoglobulins by disrupting disulfide bonds is 2-mercaptoethanol (2-ME). It has been shown that both DTT and 2-ME could be used for negating IgM agglutination in human sera during Brucella antibody screens [11]. Thus, in case DTT is absent in the laboratory, 2-ME may be added to samples instead prior to blood analysis of cold agglutinin patients. However, this was not tested in our study. 
Even though cold agglutinin disease is a rare disorder, preventing the interference of cold agglutination for CBC and peripheral blood smear analysis is difficult, time-consuming and tiresome. As presented in this report, we have used DTT to negate cold agglutination interference in such patient during CBC and peripheral blood smear tests. This novel method is remarkably practical and has the potential for allowing the clinician to assess the results of CBC and peripheral blood smear with ease and reliability.

The main limitation of this study is that only a single patient was involved, which is due to the low incidence of cold agglutinin disease cases. Further samples with cold agglutination need to be treated as described here in order to confirm the efficacy of our method. Although DTT is used for eliminating immune complexes in a number of established biochemical procedures, its use for negating cold agglutination during blood tests is described for the first time in this study. Because of this novelty, technical concerns arise, such as whether DTT in samples affects readings in a hematology analyzer, which should be addressed in a future more extensive study. Finally, we have not established whether, and if so, when the negating effect of DTT diminishes after a certain period, which is a valid possibility.

\section{Acknowledgements}

We would like to offer our regards and gratitude to our patient I.E. for his contribution and cooperation in this study. We thank Suha Sayrac for his assistance during revision of the manuscript.

\section{НОВИЙ МЕТОД І3 \\ ВИКОРИСТАННЯМ ДІТІОТРЕЇТОЛУ ДЛЯ УСУНЕННЯ ВПЛИВУ ХОЛОДОВОЇ АГЛЮТИНАЦІЇ НА РЕЗУЛЬТАТИ АНАЛІЗУ КРОВІ (А CASE STUDY)}

\section{Hamit Yasar Ellidag*, Sibel Kulaksizoglu, Esin Eren, Necat Yilmaz \\ Central Laboratories of Antalya Training and Research Hospital, Antalya, Turkey; e-mail: hayael1980@hotmail.com}

Хвороба холодових аглютинінів автоімунне захворювання, при якому антитіла атакують полісахаридні антигени на власних еритроцитах. Аглютинація та гемоліз еритроцитів призводять до хибних результатів багатьох лабораторних досліджень у пацієнтів 3 цим захворюванням, особливо результатів загального аналізу крові (ЗАК) та мазків периферичної крові. У нашій лабораторії ми зіткнулися зі зразком крові 65-річного чоловіка, в якого було діагностовано хворобу холодових аглютинінів і не вдавалося отримати вірогідні результати ЗАК або аналізу мазків периферичної крові. У пацієнта було відібрано свіжі зразки крові і проведено повторно ЗАК і аналіз мазків периферичної крові з/без інкубування на водяній бані при $37^{\circ} \mathrm{C}$. Крім того, до зразків крові, які не піддавалися термічній обробці, перед проведенням аналізу, додавали різну кількість дітіотреїтолу (ДТТ). Термічна обробка при $37{ }^{\circ} \mathrm{C}$ різної тривалості не дозволила поліпшити результати ЗАК і аналізу мазків периферичної крові. У той самий час, додавання ДТТ до зразків крові в 2-мл пробірках K3-EDTA дозволило уникнути впливу процесу холодової аглютинації на результати ЗАК і мазків периферичної крові. Наведений метод свідчить про перспективність застосування ДТТ для усунення негативного впливу холодової аглютинації за проведення ЗАК і аналізу мазків периферичної крові в пацієнтів із хворобою холодових аглютинінів. Перевагами методу є його простота та швидкість.

Ключов і слова: хвороба холодових аглютинінів, дітіотреїтол, автоімунна гемолітична анемія.

\section{НОВЫЙ МЕТОД С \\ ИСПОЛЬЗОВАНИЕМ \\ ДИТИОТРЕИТОЛА ДЛЯ \\ УСТРАНЕНИЯ ВЛИЯНИЯ \\ ХОЛОДОВОЙ АГГЛЮТИНАЦИИ НА РЕЗУЛЬТАТЫ АНАЛИЗА КРОВИ (А CASE STUDY)}

\author{
Hamit Yasar Ellidag*, Sibel Kulaksizoglu, \\ Esin Eren, Necat Yilmaz \\ Central Laboratories of Antalya Training and \\ Research Hospital, Antalya, Turkey; \\ e-mail: hayael1980@hotmail.com
}

Болезнь холодовых агглютининов - аутоиммунное заболевание, при котором антитела атакуют полисахаридные антигены на собственных эритроцитах. Агглютинация и гемолиз эритроцитов искажают многие результаты ла- 
бораторных исследований у пациентов с этим заболеванием, особенно результаты общего анализа крови (ОАК) и мазков периферической крови. В нашей лаборатории мы столкнулись с образцом крови 65-летнего мужчины, у которого была диагностирована болезнь холодовых агглютининов, и не удавалось получить достоверные результаты ОАК или анализа мазков периферической крови. У пациента были отобраны свежие образцы крови и повторно проведены ОАК и анализ мазков периферической крови с/без инкубирования на водяной бане при $37{ }^{\circ} \mathrm{C}$. Кроме того, к образцам крови, которые не подвергались термической обработке, перед проведением анализа, добавляли различное количество дитиотреитола (ДТТ). Термическая обработка при $37^{\circ} \mathrm{C}$ различной продолжительности не позволила улучшить результаты ОАК и анализа мазков периферической крови. В то же время, добавление ДТТ к образцам крови в 2-мл пробирках K3-EDTA позволило избежать влияния процесса холодовой агглютинации на результаты ОАК и мазков периферической крови. Представленный метод свидетельствует о перспективности применения ДТТ для устранения негативного влияния холодовой агглютинации при проведении ОАК и анализа мазков периферической крови у пациентов с болезнью холодовых агглютининов. Преимуществами метода являются его простота и скорость.

К люче вы е с л о в а: болезнь холодовых агглютининов, дитиотреитол, аутоиммунная гемолитическая анемия.

\section{References}

1. Swiecicki PL, Hegerova LT, Gertz MA. Cold agglutinin disease. Blood. 2013; 122(7): 11141121.
2. Berentsen S, Ulvestad E, Langholm R, Beiske K, Hjorth-Hansen H, Ghanima W, Sørbø JH, Tjønnfjord GE. Primary chronic cold agglutinin disease: a population based clinical study of 86 patients. Haematologica. 2006; 91(4): 460-466.

3. Berentsen S. How I manage cold agglutinin disease. Br J Haematol. 2011; 153(3): 309-317.

4. Lechner K, Jäger U. How I treat autoimmune hemolytic anemias in adults. Blood. 2010; 116(11): 1831-1838.

5. Ercan S, Calışkan M, Koptur E. 70-year old female patient with mismatch between hematocrit and hemoglobin values: the effects of cold agglutinin on complete blood count. Biochem Med (Zagreb). 2014; 24(3): 391-395.

6. Solanki DL, Blackburn BC. Spurious red blood cell parameters due to serum cold agglutinins: observations on Ortho ELT-8 cell counter. Am J Clin Pathol. 1985; 83(2): 218-222.

7. Kalyani R, Thej MJ, Thomas AK, Raveesha A. Chronic Cold Agglutinin Disease: A Case Report with Review of Literature. J Clin Diagn Res. 2012; 6(3): 480-482.

8. Arndt PA, Leger RM, Garratty G. Serologic findings in autoimmune hemolytic anemia associated with immunoglobulin $\mathrm{M}$ warm autoantibodies. Transfusion. 2009; 49(2): 235242.

9. Cleland WW. Dithiothreitol, a New Protective Reagent for SH Groups. Biochemistry. 1964; 3(4): 480-482.

10. Stevens R, Stevens L, Price NC. The stabilities of various thiol compounds used in protein purifications. Biochem Educ. 1983; 11(2): 70.

11. Klein GC, Behan KA. Determination of brucella immunoglobulin $\mathrm{G}$ agglutinating antibody titer with dithiothreitol. J Clin Microbiol. 1981; 14(1): 24-25. 